City University of New York (CUNY)

CUNY Academic Works

\title{
ASSESSMENT OF THE IMPACTS OF URBANIZATION ON LAND- USE AND LAND-COVER CHANGES USING REMOTE SENSING AND PYTHON AT GAZIPUR DISTRICT, BANGLADESH
}

\author{
Atika Rahman Akji \\ Bangladesh University of Professionals \\ Nowshin Ahsan Priyanka \\ Bangladesh University of Professionals \\ Anwar Zahid \\ Bangladesh Water Development Board \\ Muhammad Qumrul Hassan \\ University of Dhaka \\ Jowaher Raza \\ University of Dhaka
}

See next page for additional authors

\section{How does access to this work benefit you? Let us know!}

More information about this work at: https://academicworks.cuny.edu/yc_pubs/305

Discover additional works at: https://academicworks.cuny.edu

This work is made publicly available by the City University of New York (CUNY).

Contact: AcademicWorks@cuny.edu 


\section{Authors}

Atika Rahman Akji, Nowshin Ahsan Priyanka, Anwar Zahid, Muhammad Qumrul Hassan, Jowaher Raza, and Nazrul I. Khandaker

This poster is available at CUNY Academic Works: https://academicworks.cuny.edu/yc_pubs/305 
CONNECTS

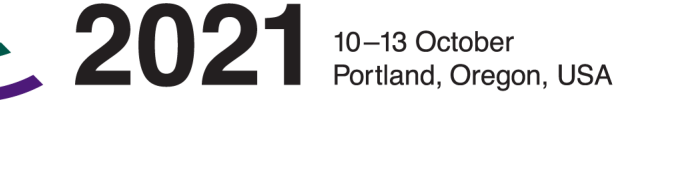

Abstract ID: 366922
Atika Rahman Akhi
Department of Environmental Science, Bangladesh University of Professionals,
Dhaka, Bangladesh, 17531042 Q astudent.bup.edu.bd, Cell: + (880) 01878700315
Nowshin Ahsan Priyanka
Department of Environmental Science, Bangladesh University of Professionals, Department of Environmental Science, Bangladesh University of Professionals,

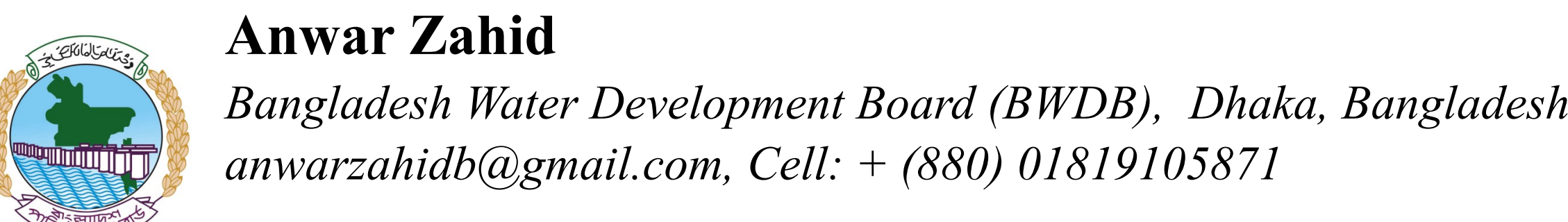

\section{Muhammad Qumrul Hassan}

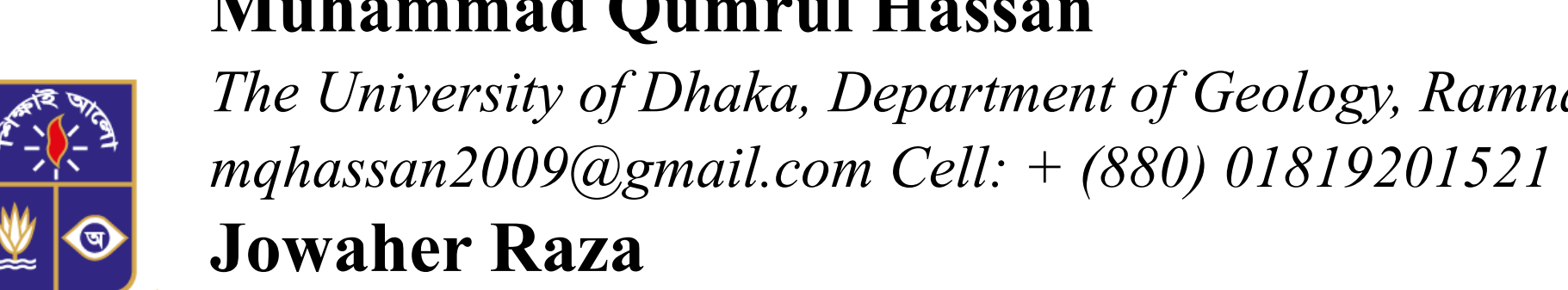
Jowaher Raza
The University of Dhaka, Department of Geology, Ram
Nazrul Khandaker

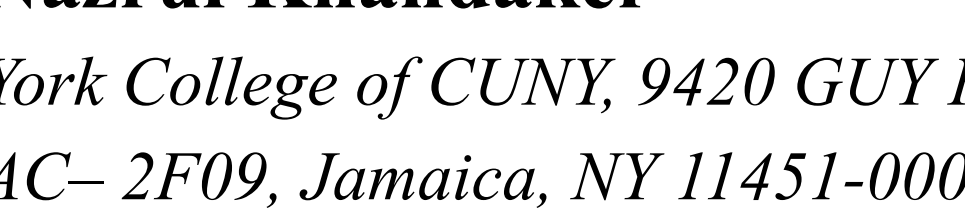

\section{Introduction}

Urbanization is one of the critical anthropogenic activities which causes habitat destruc-
tion, ecosystem loss, and decline of natural vegetation. Urbanization is a primary concer for a developed country, as land-use patterns change unexpectedly and total agricultur
land lessens rapidly. The study area is near the capital city of Bangladesh. For the last two decades, urbanization has grown rapidly and unexpectedly in developing countrits struggles that work as barriers to achieve the MDG and SDG goals within 2030 For the expansion of population growth, agricultural lands are converted to residential areas. The environmental parameters have been changing for this unplanned urbanization, and the
topsoil quality is degrading rapidly. Collaborating GIS, RS, and Landsat iaginary work
will bring a unique perspective in reducing unplanned urbanization. Abstract

$$
\begin{aligned}
& \begin{array}{l}
\text { Key Variables and their interac- } \\
\text { tion on Urbanization }
\end{array}
\end{aligned}
$$

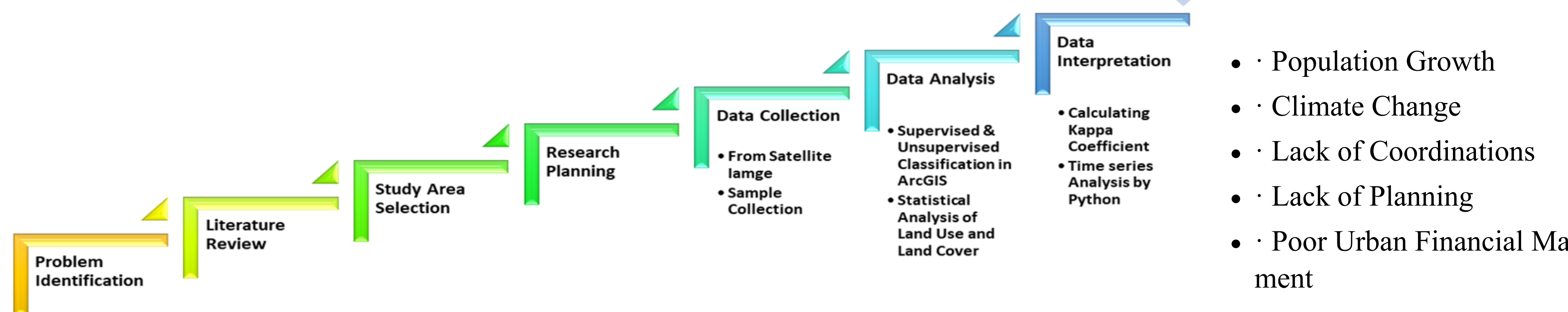

Urbanization has been the major demographic trend globally. Mapping is vital for the analysis of land use and land cover. Using open-source Landsat data integrated with GiS technologies and other ancillary data
(Toby et al., 2000), thins study attempts to classify land use in unsuppervised classifitcation and create land cover maps in Gazipur Sadar and Kaliakair, rapidily growing urban and industrial zones. We used pytho
coding to enable post-classification change detection analysis. This study quantitatively xamined changes in land use/land cover and urban expansion in the studyy area. Gazipur is a growing metropolitan city north of the capital city of Dhaka in Bangladesh, experiencing rapid industrialization followed by u.-

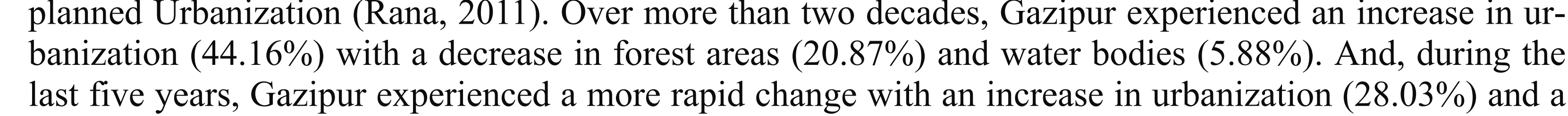
last five years, Gazipur experienced a more rapid change with an increase in urbanization $28.03 \%$ ) and
decrease of forest areas $(26.29 \%)$ and water bodies $(8.92 \%)$. These changes caused enviromental degrra dation, land use pattern change, topsoil degradation, and habitat destruction (Al Ahmadi et al., 2009). A significant change in vegetation pattern took place since 1991 . The findings of this study and the geospa
tial information generated from the land use mapping can be used as an essential reference for planners policymakers, stakeholders, and other interested groups

Unsupervised Classification of Land use result for 1995, 2000, 2015, 2020

The maps presented in the figure show that the primary classes are agricultural land, bare land, forest, urban area, and the water body of Gazipur Sadar \& Kaliakair at 1995, 2000, 2015, 2020.

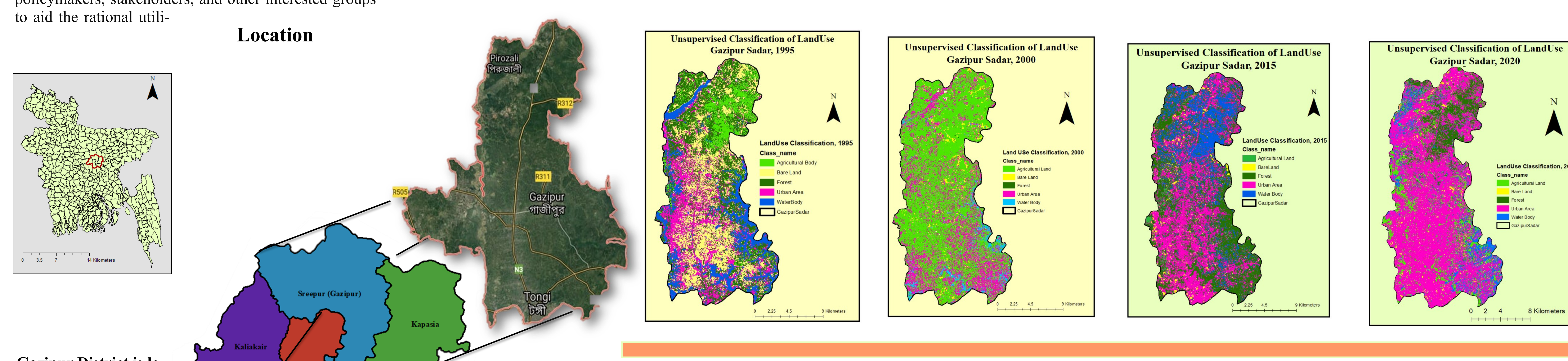

\section{Gazipur District is lo-
cated just north of the} cated just north of the
capital city of Dhak
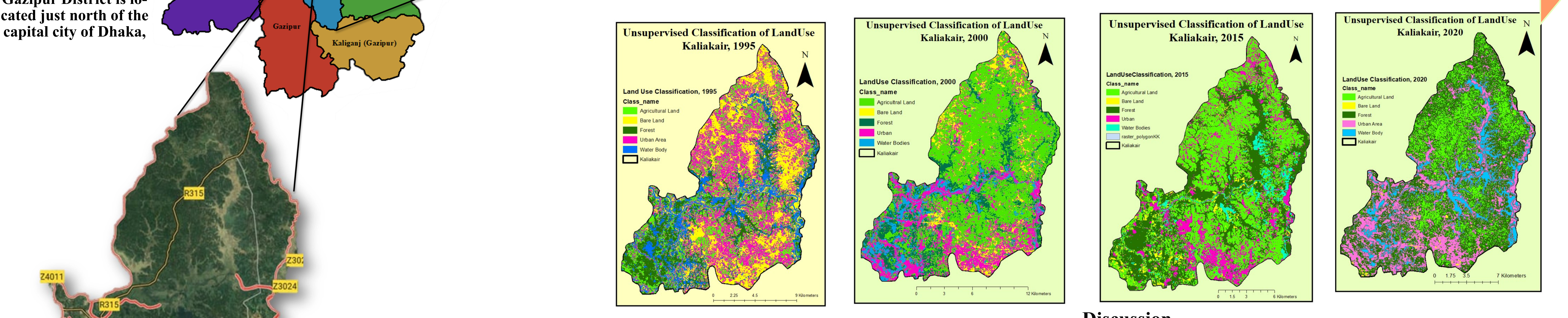

Discussion

ne dramatic changes in land cover, as evidenced by rapid increase in the extent of the built-up regions, resulting in a loss of croplands, vegetation cover, fallow lands, water bodies
and lowlands. These rapid urban expansions have been mainly driven by massive growth in the industry, infrastructure development, population growh, 2020 between Gazipur Sadar \& Kaliakair show the changes in Land Use and Land cover due to unplanned urbanization and indus-

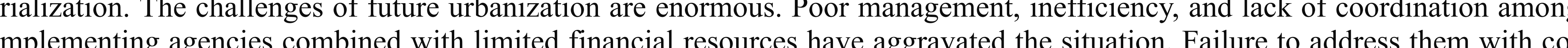
ordinated and robust planning will have disastrous consequences. Sound planning, a well-thought-out strategy, muscular coordin-

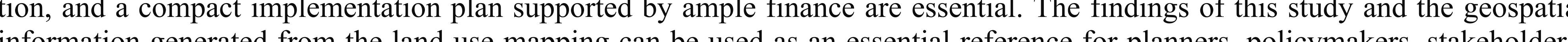
information generated drom the land use mapping can be used as an essential reference for planners, policymmakers, stakeholders,
and other interested groups, to aid in the rational utilization of limited land resources. Additionally, the intormation may assist in
making decisions regarding future lane

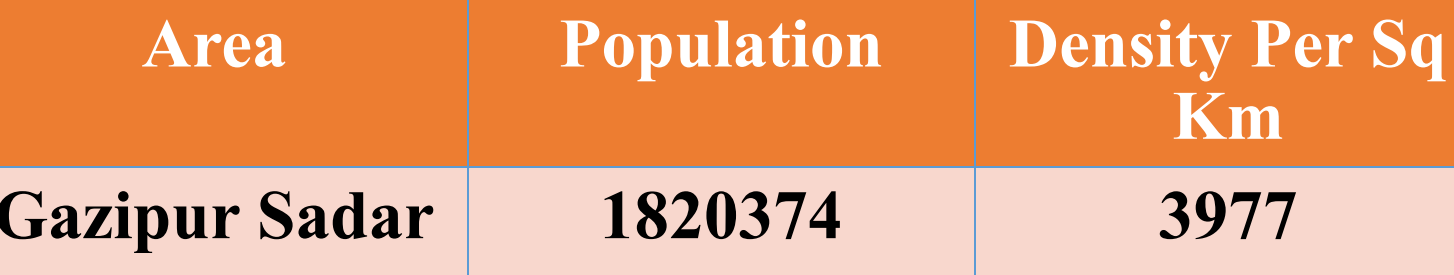
\begin{tabular}{l|l|l} 
Kaliakair & 483308 & 1539
\end{tabular}

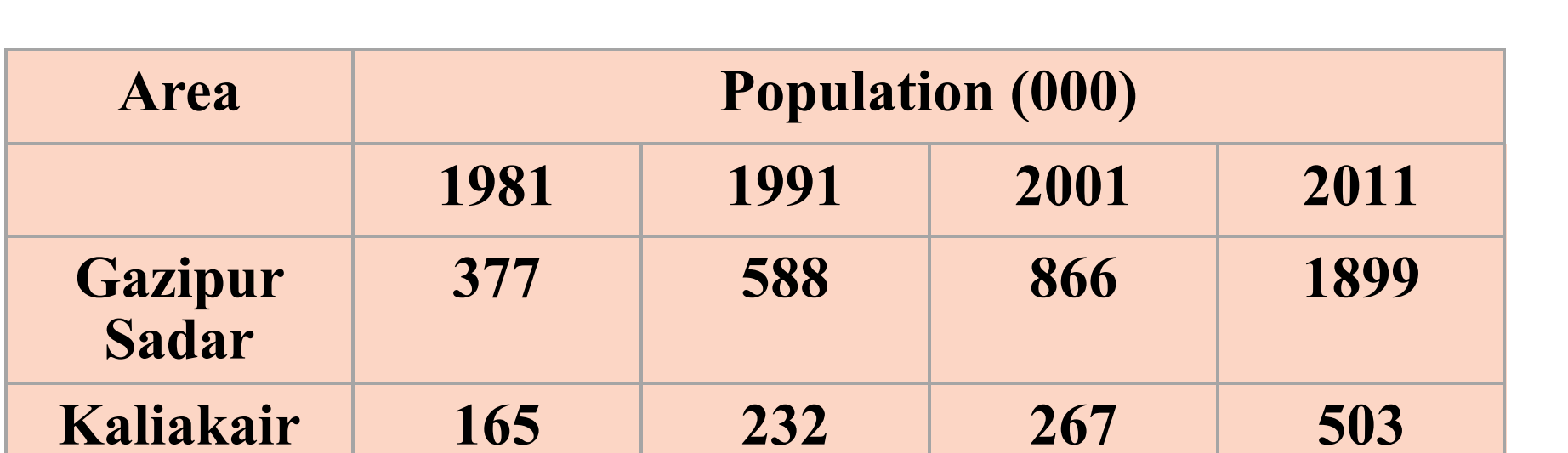

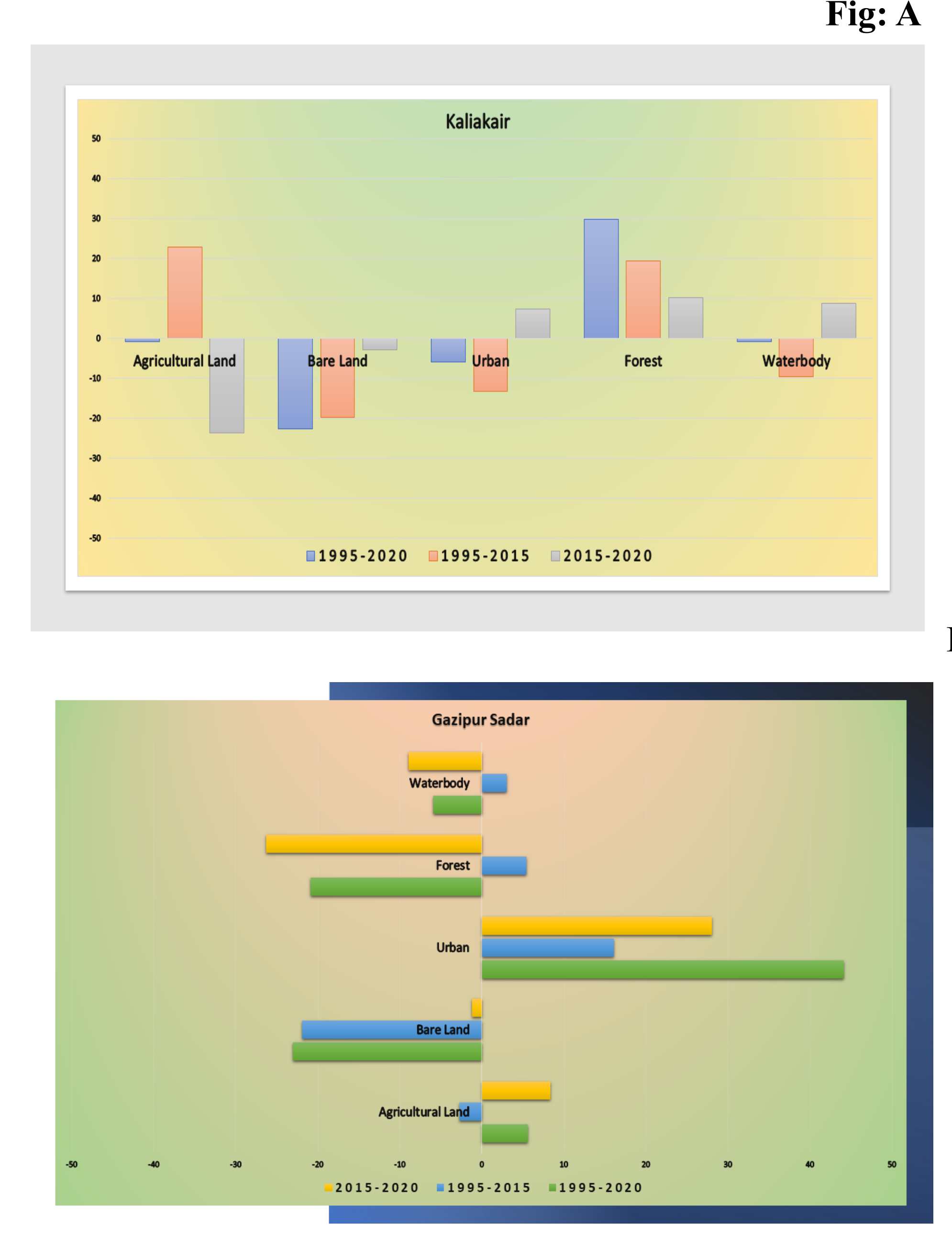

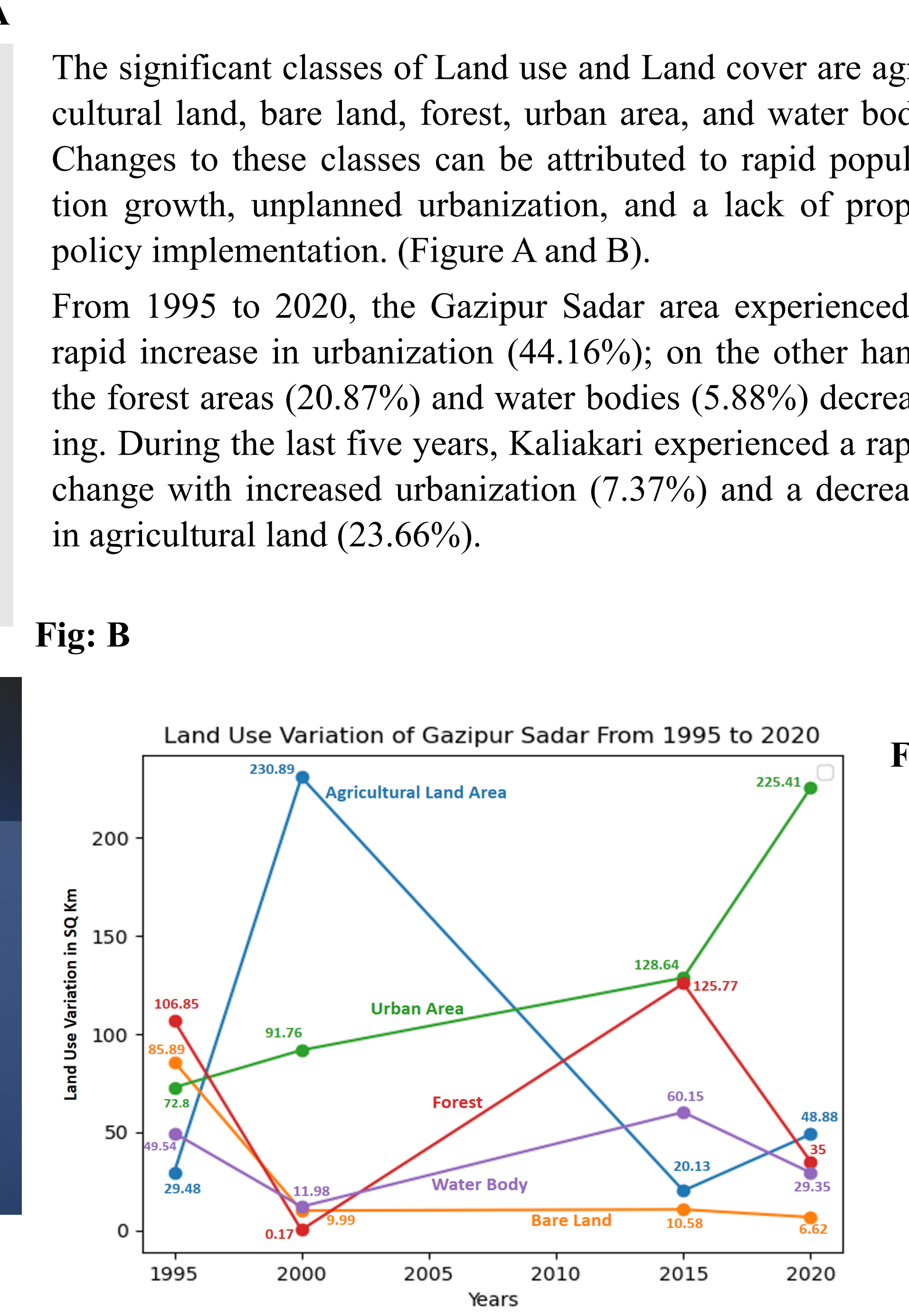

At Gazipur, the urban area was $91.76 \mathrm{sg} \mathrm{km}$ in
2000 , and in 2020 the metropolitan area in-

creased $225.41 \mathrm{sq} \mathrm{km}$. The agriculture area i

km, and in 2020 the place is $48.88 \mathrm{sq} \mathrm{km}$.
(Figure C)

At Kalikair, the urban area was $41.62 \mathrm{sq} \mathrm{km}$ in
2000 , and in 2020 the metropolitan area in-
creased to 71.56 sq km The aliculture arecreased to $71.56 \mathrm{sq} \mathrm{km}$. The agriculture area
is decreasing, in 2000 the earea was $160.69 \mathrm{sq}$
$\mathrm{km}$, and in 2020 the decreased $50.49 \mathrm{sg} \mathrm{km}$.
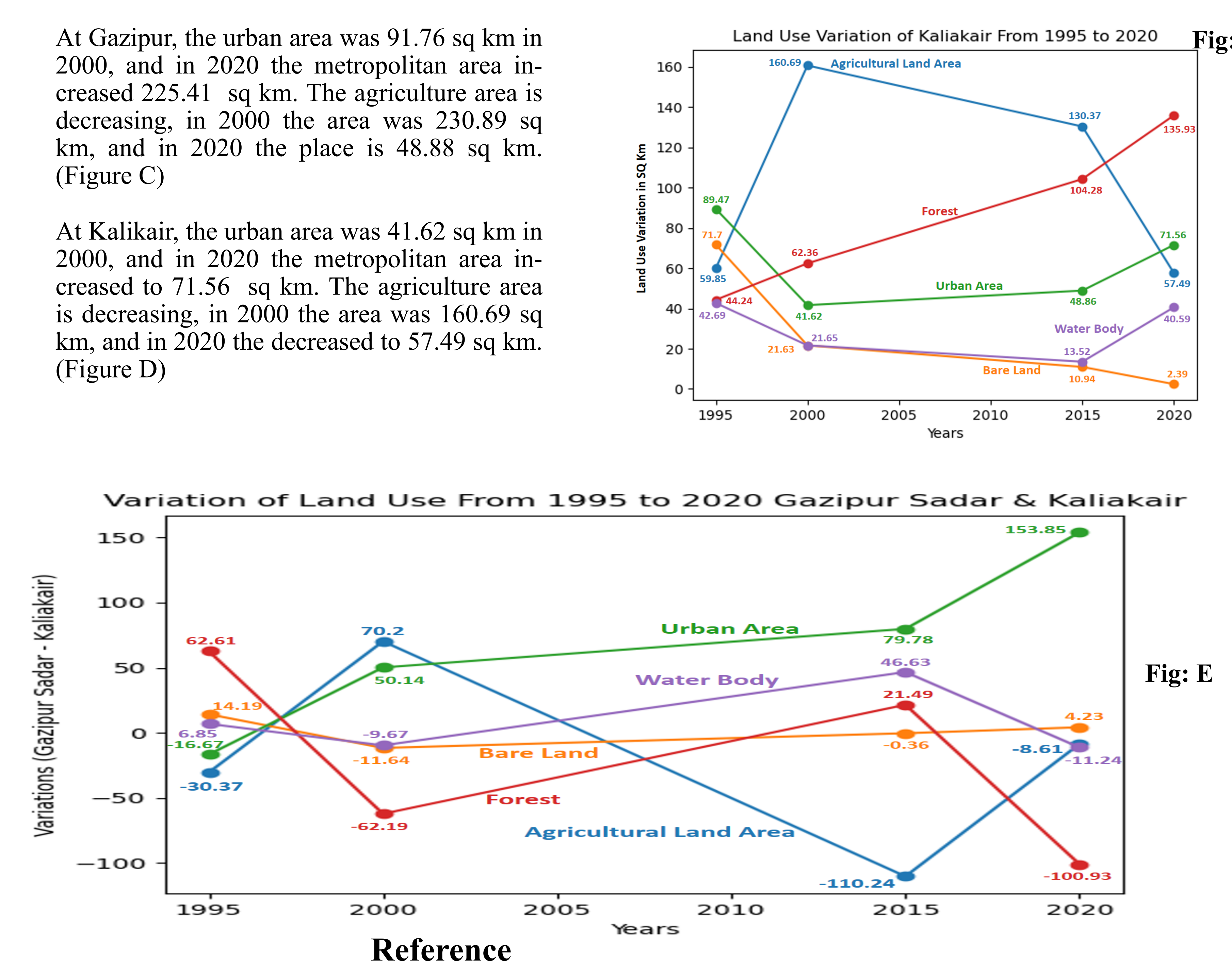
Al-Ahmadi, F, S. and Hames, A, S. 2009, “Comparison of Four Classification Meth-
ods to Extract Land Use and Land Cover from Raw Satellite Images for Some Remote Arid Areas, Kingdom of Saudi Arabia", Journal of King Abdulaziz Universit Dewan, A.M. and Yamaguchi, Y. (2009) Land Use and Land Cover Change in GreatApplied Geography, 29, 390-401.

Rana, M. M. P. (2011). Urbanization and sustainability: challenges and strategies for sustainable urban development in Bangladesh. Environment, Development and Sustainabiln, 13, 237-256 Roy, P. and Giriraj, A. (2008). Land use and land cover analysis in Indian contex

Toby N. Carlson, S. Traci Arthur, (2000) The impact of land use - land cover spective. Global and Planetary Change 252000 49-65

\section{Department of Environ-} esh University of Profes(BuP) - Department of Geology, Faculty of Earth and Environmental Sciences,
versity of Dhaka. 